\title{
MeEting THE CHALLENGE OF THE WORK-LIFE BALANCE IN THE South African workplace
}

\author{
G F Mageni and A D Slabbert
}

Faculty of Management, Cape Peninsula University of Technology

\begin{abstract}
The work-life balance (WLB) construct as a business imperative has been of growing concern in organisations outside South Africa for the past two decades, particularly given the pressure to create a sustainable global competitive advantage through human capital. Within the last decade this aspect has been prominent in various forums. However, no studies as yet provide insight into the applicability of WLB models to the South African workplace. The present article therefore explores the composition of a WLB system, and analyses constraints on its application under the conditions of the South African labour market.
\end{abstract}

JEL J22, J24, M12, M54

1

\section{Introduction}

A reality of today's workforce is that workers hold a number of different roles in life. People increasingly juggle a range of activities, interests, and relationships outside work while still striving to meet growing demands in the workplace for quality goods and services around the clock. Can employers run a demanding business and still let their employees run their lives? This is a problem more and more South African companies are facing as they struggle to compete in a $24 / 7$ take-no-prisoners economy. The rise of this problem, and increasing awareness of it in the business sector, have led many international organisations to adopt work-life balance (WLB) policies as early as two decades ago. However, even though a few dynamic multinational corporations (MNCs) in South Africa have attempted to adopt a similar approach, their policies tend to remain impractical. The worth of these policies in terms of value added to the bottom-line has also not been proven. In light of South Africa's undeniable integration into the "new globalised world economy", this article focuses on the application of the international WLB system in the unique circumstances governing the South African workplace.

Pillinger (2001-B: 1) defined WLB as: "The adjustment of work patterns in such a way that everyone, regardless of age, race or gender can find a rhythm that enables them more easily to combine work and their other responsibilities and aspirations". The concept of work-life balance is receiving increasing international recognition. For example, one search engine (http://web.intorac.galegroup.com) consulted in November 2004 indicated 5260 hits for this concept.

\section{2}

\section{Theoretical background}

Debates around WLB reveal some interesting insights into a politics of work that reflect new ideas and practices relating to how work can be exchanged and changed, redistributed and shared in order to balance work and life. According to Pillinger (2001-B), the WLB concept is a live issue across Europe, and is very much on the political agenda in the United Kingdom. Johnston and Packer (1987) support this view, citing fourteen years of research already conducted on the WLB phenomenon 
in Europe, which has yielded substantial proof of its contribution to organisational wellness. The modern world of work has a workforce that is more ethnically diverse. This workforce has a larger proportion, compared to that of working women, dual-earner families, workers with a skills shortage and sandwich employees (employees taking care of children, elders or other dependents). This younger generation of workers also shows a shift in expectations of quality work life. Rose (2005) suggests that companies have realised that giving employees extra time off to attend to personal business links directly to higher job satisfaction.

According to Lowe (2000), there has never been a better time to talk about WLB in the workplace. Morale is down and companies have to work out how to support post-layoff survivors so that their workload is manageable and business goals are achieved. Duxbury, Dyke and Lam (2000) support this argument in a paper that provides insight into the new tendencies visible in WLB models. They suggest that organisations that adopt initiatives to help employees achieve a better balance between work and life outside of work focus on achievement and quality performance. This reflects the ability of business to build more resilient organisations, which are better able to adapt and be successful. The research results presented by Lowe and Schellenberg (2001) agree with this view, and also suggest that such WLB initiatives can further benefit businesses by giving them good reputations as "best practice employers", thus helping them to attract better talent. This benefit will impact directly on the bottom-line.

A solid business case can therefore clearly be built for the effective application of a WLB system. Although the company's goals often take priority within a modified system, most employers agree that people do their best work when they can optimally balance their jobs with the rest of their lives. This understanding of reality is also applicable to the South African economic situation because of its integration into the global network. The basic arguments for the integration of WLB concepts into the South African economy are therefore undeniably the realities created by the nature of the new economy. Research conducted by Lero and Johnson (1994) indicates that, during the past decade, the wellness levels of organisations in South Africa have come under increasing pressure. Both intensified international competition and the blurred lines of responsibility between job and family contribute to this pressure. According to Van Niekerk and Douglas (2003), WLB became a reality amongst a few dynamic South African companies about ten years ago and is manifested in their policy formulations. However, an important shortcoming of their research is that the sample is not representative of the entire South African business community, since it includes only organisations with international ties (MNCs).

Research results suggest that the current underlying principle of WLB systems is the enforcement of good management practice and sound business sense in the view of the managers of many MNCs. Further investigations, however, indicate that full implementation of WLB faces a number of complications. WLB policies are widely advertised on websites, but in-depth investigation highlights that the practical application and monitoring of such systems often lacks substance.

In South Africa, many organisations still feel that helping employees balance competing work and non-work demands is not their responsibility (Bird, 2003). In the public sector particularly, organisations tend to subscribe to a somewhat dated view called the "myth of separate worlds". This is based on the premise that work is work and life is life and the two domains do not overlap. The perception aired is that companies are in the business of increasing shareholder value and serving customers and not of helping employees cope with stress. Supporting this viewpoint are the results of the 2003 Human Capital Satisfaction Survey, which show that only 60 per cent of employers who participated in the survey indicated that balancing work and non-work lives is important. Management's perspective is all too often that "Our workers are focused on the task" (Czakan, 2003: 2). South African managers therefore have to perceive their challenge is to learn how to manage and 
measure worker output rather than the workers themselves. Reality indicators support this, since productivity rates are increasing at a much slower rate in South Africa compared to its major trading partners. Therefore the unit labour costs, which ultimately reflect the real value added by productivity, increase dramatically (Barker, 2002).

The South African concept of WLB can thus be seen to still be lacking in the sense that no practical value-adding models are established as guidelines for smaller organisations.

South African businesses have learned through experience that, though South Africa is operating in a globalised, integrated economy, all practices need to be adapted to cater for the unique circumstances of the South African workplace.

WLB is a comprehensive concept and can mean different things to different people. According to Canabou (2001), the fundamental aim of WLB is to connect the seemingly contradictory goals of the individual and the organisation, working towards congruent practices. The conclusion drawn is that, contrary to popular belief, companies do not have to pit the needs of the employees against those of the business. WLB requires organisations to discard many ingrained rules and to rethink the way the job gets done.

Duxbury and Higgins (2001) identify a comprehensive range of WLB options, covering flexible working arrangements, flexible benefit packages and employee assistance programmes.

Assessment of their data leads to the conclusion that managing and measuring a range of different systems can become an added nightmare in the already challenging South African workplace, which is currently struggling with important issues such as employment equity. However, the data also suggests that WLB warrants consideration by employers, since implementation of these systems in order to support the notion of human capital is one of the keys to sustaining a competitive advantage. Results also show that the economic intellectual capacity of the organisation's workforce should be considered in the selection of the various systems, because implementation of an unsuitable system could contribute to the deterioration of work ethic experienced amongst certain segments of the South African workforce.

Studies focusing on the realities of the South African work environment show an increase in work-life conflict, and so support a quest for applicable WLB systems (Duxbury \& Higgins, 2001). Recent dramatic changes in the nature of work and the roles of new technologies have led to a greater proportion of workers experiencing greater challenges in balancing their roles as employee, parent, spouse, etc. (Pleck, 1995). Comparison of the results of studies by Pleck in 1995 and Duxbury and Higgins in 2001 suggest that jobs, especially in the South African business environment, have overall become more stressful and less satisfying over this period. These studies specifically mention an increase in work-life conflict .

As a direct consequence of globalisation and internationalisation, retrenchments and layoffs are an ever-present reality on the South African labour front. WLB could conceivably therefore be regarded as an economic luxury. This view is supported by Ngambi (2001: 5) who states that "the challenges (problems) facing most of the organisations in the South African labour markets include high levels of unemployment and massive retrenchments which affect the strategic human resource management processes". In order to strike the delicate balance between these realities, alternative options and routes should be investigated and examined for possible utilisation in the individual company context. One of these would be job-sharing, a situation where two or more employees share a job, which could theoretically be filled by one employee. In this context, Ngambi (2001: 25) concludes that "it is highly recommended that all the stakeholders explore the use of job-sharing as a viable alternative solution to these problems".

As this view suggests, WLB under its international aspect will have a fundamental struggle for recognition and full utilisation in South Africa, especially amongst smaller employers. This position is supported by Greef and Nel (2003: 55) who, recognising the complexity of job-sharing, state that "such cost 
considerations as rates of turnover and absenteeism, recruitment, training, fringe benefits, and the potential for increased flexibility should be taken into account as well".

The modern reality is that South African businesses are getting more involved in a global interdependent network of economies. The problems faced by big overseas organisations can therefore be expected to manifest in the South African economy, though not in exactly the same form, of course, and therefore WLB will have to become a national concern.

\section{3}

\section{Research methodology}

Two major MNCs were chosen and their extensively advertised WLB policies analysed as to implementation and enforcement of working practices. Both these MNCs operate in the petroleum industry and have shown awareness of the need for WLB over the last decade. Their only disadvantage as research subjects is that, since they are employers of choice, it becomes difficult to tell whether or not WLB in fact contributes toward their status as favoured employers. Due to the sensitive nature of the information disclosed, the organisations will not be identified.

Enquiry into WLB implementation in South Africa was relatively unstructured due to the complex nature of this very broad phenomenon. Essentially, data was collected during unstructured information-sharing interviews conducted with employees of the chosen organisations. This lack of structure is a very real limitation of the present study, and a much more focused enquiry into the application of particular and specific aspects of WLB in organisations is recommended. The present enquiry should thus be regarded as exploratory and, at best, speculative in nature.

A total of twelve senior managers were interviewed, as well as twenty three middle level managers and forty seven non-managerial employees from the two MNCs. The findings can be broadly summarised.

\section{4}

Results

\subsection{Organisation 1}

Interviews conducted at this organisation revealed that WLB initiatives have been operating since 1994. These initiatives originate in the Head Office. The policies reflect a range of flexible working arrangements and work-life assistance programmes, including:

- Employee assistance programmes (no defined elements),

- Flexible working arrangements,

- Reduced hours,

- Reduced workloads,

- Continuing part-time practices,

- Flexitime and

- Telecommuting.

A significant shortcoming of all these programmes is the lack of control or measurement of the relationship between these practices and business deliverables. The discussions held with employees and management provided insight into the difficulty of accessing these practices on an ongoing basis. One statement from a manager expresses this concern: "How do we exercise these things on elementary jobs like our information analysts, who are already short staffed?" This reflects the realities that organisations need to deal with when a WLB system is considered.

\subsection{Organisation 2}

This organisation takes pride in its claim to have an optimally developed WLB system that is fully supported by global controls and accountability structures. WLB as a strategic objective is identified as one of the key performance indicators on the organisation's human resources scorecard. However, the results of the Global People Survey of 2002 prove nondelivery of WLB targets due to non-supportive objectives. Even though the organisation's WLB system has been in place for ten years, it gained the lowest score amongst employees. The following diagram indicates full results. 
Figure 1

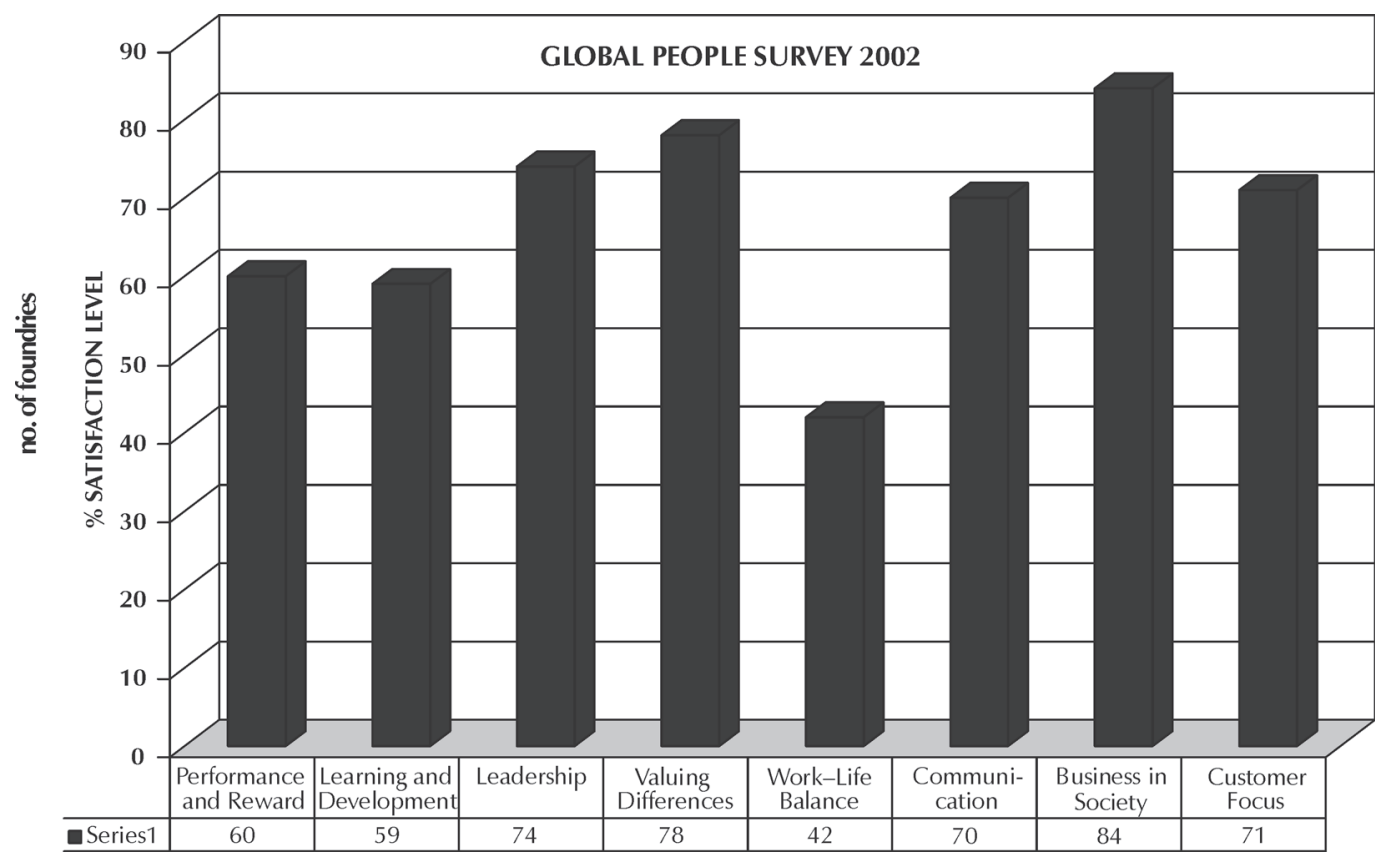

Personnel targets reflected in the WLB Scorecard include:

- addressing concerns relating to excessive travel and workload,

- promoting the use of teleconferencing,

- conducting meetings between 08:00 and 17:30 local time,

- including spouse programmes in zonal meetings,

- e-mail policy with regard to weekends,

- in-house recreational programmes,

- flexible approaches to work, including working from home, and

- enforcing a leave policy.

Discussions with management and employees indicate that as many as 60 per cent of the organisation's employees are still subjected to support functions modelled according to traditional work systems. The concern is that although these "nice-to-have" policies are advocated, the jobs are still split up in narrow functions with short repetitive work cycles. The workforce profile of this organisation clearly shows that only 40 per cent of staff are able to take full advantage of the current WLB system. Internal logistical problems are widespread, such as a shortage of portable business units and positions which are fully "de-jobbed" (working on projects and not a conventional nine-to-five job). The WLB system is restrictive in the sense that a top-down approach is maintained, which does not assess the needs of the bulk of the organisation's employees. Involving the staff from all levels is necessary to ultimately ensure the effectiveness and viability of the system. This poses a further challenge to the workforce, because total involvement will require employees to judge what is good for the business and for themselves.

\section{5}

\section{Discussion}

A few dynamic organisations in South Africa have sought to introduce a few forms of WLB flexibility. This indicates a drive towards some sort of WLB approach (Van Niekerk \& Douglas, 2003). However, all of these approaches, 
although useful forms of WLB, have too strong a focus on hours of work with little regard to outputs achieved (Whithers, 2001). As stated previously, this paper is not arguing against WLB systems as a concept, but on the contrary advocates the implementation of WLB systems provided they take into account the structural and social conditions underpinning the South African workplace. Some of these conditions include the following:

- The critical skills shortage among South Africa's economically active population (EAP) produces an average level of intellectual development or maturity insufficient for the full implementation of a comprehensive western-style WLB system. A specific example of the type of problem encountered is exploitation of "family-friendly" policies.

The maturity levels required by a WLB system are of particular concern. Hughes (2001) claims that the introduction of a comprehensive WLB system requires employees who are self-sustaining and who control their jobs, in the sense that they utilise all WLB incentives in a way that ensures the realisation of the organisation's overall business objectives. Such a workforce is intellectually focussed on the business and makes sure the WLB system is not abused, since this would hamper the achievement of business strategies. It could therefore be concluded that, in order for WLB to become a business imperative, the labour market needs to develop a workforce that is more flexible, adaptable, multiskilled, innovative, creative and mature whilst developing ownership of business strategies.

- South Africa appears to be suffering from an almost universal absence of a proper work ethic. This increases the likelihood of unnecessary absenteeism, which is a real problem in the South African workplace. Empirical studies have identified an interrelationship between work ethic and other variables, such as a decrease in productivity, trust and economic competitiveness in general. Linking the phenomenon of work ethic to the underpinning values required by a successful comprehensive WLB system raises serious questions about the readiness of the South African workplace for a WLB system.

- Organisational commitment, a concept linked to the WLB approach, measures the relationship between employees' loyalty to an organisation and its success. Various researchers agree that an individual who has a high commitment level will exert extra effort on behalf of the organisation and will have a strong desire to remain with the organisation (Mowday, Steers \& Porter, 1997). Various investigations have all suggested that the overall commitment level of the South African workforce is questionable. The South African workforce is also fairly unique in its clear polarisation between highly committed and poorly or non-committed employees (Eby \& Freeman, 1999). In the context of work ethic, variables such as job satisfaction and levels of motivation collectively enhance the commitment levels of employees. Organisational commitment in its totality forms part of the value system needed for the effective implementation of a WLB system that contributes to the success of the business.

- Full implementation of some of the elements of a comprehensive WLB system may involve adjustments that border on alterations of employees' conditions of employment. This poses a unique challenge in the South African workplace in the context of the implementation of a cloned WLB system. Barker (2003) suggests that the trade union movement in South Africa still tends towards a militant approach towards new economic workplace practices, because of the perceived linkages between these practices and job losses. This is in contrast to many overseas-based organisations, which have been shown to have a more responsive approach to changes in the South African economy. Flexibility is enhanced, because the third force is either 
eliminated or curtailed and direct negotiations with the workforce focusing on the "bottom-line" can take place (Hochschild, 1990).

- The WLB approach does not require adaptations modelled to the needs of the new economy from management and employees only, but also, and more importantly, from the human resources (HR) professionals who drive the process of organisational change. Lowe and Schellenberg (2001) point out that the true role of HR in a WLB system is to be the driving force of the project. This requires the strategic alignment of the HR strategy with the overall business strategy, facilitated by a pivotal relationship between line management and HR professionals. Research by the Human Sciences Research Council (2002) shows that in most South African organisations HR functions are still restricted to managing nuisance factors such as the administration function. Capacity building ventures are needed to prepare HR departments for the new trends of the globalised economy. Specific emphasis should be placed on developing competencies that will allow HR professionals to approach soft-edged issues (propagated by a WLB system) with a business-oriented frame of mind.

- Steinberg (2001) suggests that in order to be successful a comprehensive WLB system has to be supported by a flexible legislative framework. The South African Labour Legislation is however notorious for its rigidity in the face of the realities of the business world. While there appears to be a genuine desire on the part of government to balance power, most changes favour the union (and thus the employees) rather than the business itself. As mentioned before, the WLB approach requires a flexible approach towards work practices, in order to allow individual organisations to regulate the system through balancing employees' needs with those of the business. Thus in the over-regulated legislative framework of South African labour, this type of common-good interaction cannot be exploited to its fullest extent.

\section{6}

\section{Conclusion}

A WLB system after the international model in its purest form cannot be applied in the South African workplace, due to the widespread lack of twenty-first-century business competencies. According to Van Niekerk and Douglas (2003), the conventional notion of an employment contract is challenged by the WLB system. Therefore the South African workforce is in critical need of new competencies that fit into the profile of the WLB approach.

Competencies required from employees would include the ability to:

- self-manage output requirements,

- drive self-learning and ownership and

- self-drive measurable results.

Competencies required from management would include the ability to:

- manage output more than people,

- identify value-adding practices and provide performance enablers and

- lead by example, living out the characteristics of integrity and trust that should form the basis of partnerships between employer and employee.

The dimensions of the productivity/employee wellness dichotomy have also increased in South Africa over the past decade, a trend that warrants urgent attention. There has been a suggestive move towards implementing flexible workplace practices in a few of the more dynamic South African companies. A major identifiable shortcoming in these companies' WLB systems is the lack of strategic intervention within policy formulation as well as the inability to synthesise WLB policies into the organisations' cultures. The internal and external forces steering overseas organisations towards adopting a more practical approach towards WLB are present in similar magnitude in South African workplaces. However, unique 
constraints within the South African labour market act as significant obstacles to the success of a comprehensive WLB approach. It is imperative that organisations that currently have WLB policies in place should change their approach from a solely employee-centred focus towards a more comprehensive business base for the system. Extensive international results suggest that a whole spectrum of measurable benefits or value-adding practices can result from a WLB system. However, this still needs to be explored in South Africa through focused research. The major challenge in the implementation of a WLB system in the South African context will face management, which has to learn to manage worker outputs, rather than the workers. The findings of this research study stress both the need to manage transition towards a flexible firm, and also the necessity of balancing flexibility and security in order to guard against the abuse of a WLB system.

\section{References}

1 BARKER, F. (2002) The South African Labour Market: Critical Issues for Renaissance, Van Schaik: Pretoria.

2 BECKER, B.E.; HUSELID, M.A. \& ULRICH, D. (2001) The HR Scorecard: Linking People, Strategy and Performance, Harvard Business School Press: Boston, MA.

3 BENDIX, S. (2001) Industrial Relations in South Africa, 4th ed., Juta: Cape Town.

4 BHORAT, H. (2001) Labour Market Challenges in the Post-Apartheid South Africa: A Country Profile, ILO commissioned study.

5 BIRD, J. (2003) “Work-life balance: Don’t burn out your team”, http://Worklifebalance.com. (Accessed 15 July 2003).

6 CANABOU, C. (2001) Solving Work-Life Balance, Web Exclusives: California.

7 CZAKAN, T. (2003) "2003 Kelly human capital satisfaction survey”. http.//www.kelly.co.za. (Accessed 15 July 2003).

8 DUXBURY, L. \& HIGGINS, C. (1998) Worklife Balance in Saskatchewan: Realities and Challenges, Government of Saskatchewan: Regina.

9 DUXBURY, L. \& HIGGINS, C. (2001) "Worklife balance in the new millennium", $C P R N$ Discussion Paper No. W/12: Ottawa.
10 DUXBURY, L.; DYKE, L. \& LAM, N. (2000) Managing High-Tech Employees, Carswell Press: Toronto.

11 EBY, L.T. \& FREEMAN, D.M. (1999) "Motivational basis of affective organizational commitment: A partial test of an integrative theoretical model", Journal of Occupational and Organisational Psychology, 72:463.

12 GREEF, A. \& NEL, P.S. (2003) "Employment transformation enhancement in South Africa: Establishing a job-sharing model to promote employment equity", South African Journal of Labour Relations, 27(2):23-62.

13 HOCHSCHILD, A. (1990) The Second Shift, Avon Books: New York.

14 HUGHES, S. (2001) "Basic rights or red tape?", http://www.ils.com. (Accessed 17 July 2003).

15 HUMAN SCIENCE RESEARCH COUNCIL. (1999) "HSRC Study: Skills shortage in the South African labour." http://www.hsrc.ac.za. (Accessed 25 August 1999).

16 HUMAN SCIENCE RESEARCH COUNCIL. (2002) "HSRC Study: Skills shortage in the South African labour." http://www.hsrc.ac.za. (Accessed 25 August 1999).

17 IPMA STAFF. (2003) "The impact of globalization on human resource management." http://www.ipma-hr.org. (Accessed 15 July 2003).

18 JICK, T. \& MITZ, L. (1985) "Sex differences in work stress", Academy of Management Review, 10:408-420.

19 JOHNSTON, W. \& PACKER, A. (1987) Workforce 2000: Work and Workers for the 21st Century, Hudson Institute: Indianapolis.

20 KROM, P. (1999) "Shell people principles for working together: Finding our own balance between work and personal life. http:// www.shell.co.za. (Accessed 7 September 2003).

21 LERO, D. \& JOHNSON, K. (1994) 110 Statistics on Work and Family, Canadian Advisory Council on the Status of Women: Ottawa.

22 LOWE, G. (2000) The Quality of Work: A People Centred Agenda, Oxford University Press: Toronto.

23 LOWE, L. \& SCHELLENBERG, G. (2001) "What's a good job? The importance of employee relationships", (CPRN Study No. W/05) Canadian Policy Research Network: Ottawa.

24 MILLER, B. (2001) How HP Solved the WorkLife Conundrum, Web Exclusives: California.

25 MOODY, M. (2003) "The importance of balance", http://workthing.com. (Accessed 7 September 2003). 
26 MOWDAY, R.; STEERS, R. \& PORTER, L. (1997) "The measurement of organisational commitment", Journal of Vocational Behaviour, 14:224-247.

27 NGUMBI, H.C. (2001) "Job-sharing: An alternative to lay-offs and unemployment in South Africa?", South African Journal of Labour Relations, 25(1):4-34.

28 PE CORPORATE SERVICES. "SA's public holiday siesta burdens economy", Sunday Times, April.

29 PILlinger, J. (2001a) Quality in Social Public Services, European Foundation for the Improvement of Living and Working Conditions: Dublin.

30 PILLINGER, J. (2001b) Work-Life Balance: Towards a New Politics of Work and Time, ETUI: Brussels.

31 PLECK, J. (1995) The Work-Family Interface: Towards a Contextual Effects Perspective, National Council on Family Relations: Minneapolis.

32 POSWELL, L. (2002) The Post-Apartheid South African Labour Market: A Status Report,
Development Policy Research Unit UCT: Cape Town.

33 PRODUCTIVITY REPORTS "Proudfoot Consulting”, Sunday Times, October.

34 REICH, R. (2003) Business Review - Canada.

35 ROSE, B. (2005) "Some companies encourage employees to take time off," Chicago Tribune, July 24 2005. http.//webi.infotrac.galegroup.com. (Accessed 7 September 2003).

36 SCHOLTES, P.R. (1998) The Leader's Handbook: Making Things Happen and Getting Things Done, Mcgraw-Hill: New York.

37 STEINBERG, I. (2001) "Work-Life balance in the balance", http://Research@Roffeypark. (Accessed 9 September 2003).

38 THOMPSON, P. (1986) The Nature of Work, Macmillan Education: London.

39 VAN NIEKERK, L. \& DOUGLAS, T. (2003) Work-Life Balance, The HR Workshop: South Africa.

40 WHITHERS, P. (2001) "Retention strategies that respond to worker values". http:// workforce.com. (Accessed 17 July 2003). 